\title{
Effects of Hoof Trimming on Feed Consumption, Milk Yield, Oxidant and Antioxidant System in Dairy Cows with Hoof Deformities
}

Selvinaz Yakan ( $\nabla$ syakan@gmail.com )

Agri Ibrahim Cecen University https://orcid.org/0000-0002-6274-9012

\section{Research Article}

Keywords: Hoof trimming, Oxidant and antioxidant system, Animal welfare, Cow

Posted Date: April 2nd, 2021

DOl: https://doi.org/10.21203/rs.3.rs-356253/v1

License: (c) (1) This work is licensed under a Creative Commons Attribution 4.0 International License.

Read Full License 


\section{Abstract}

In this study is objectived to reveal the importance of hoof trimming (HT) in cows by determining the changes in feed consumption, milk yield, oxidant, and antioxidant parameters in the days before and after $\mathrm{HT}$ in cows with hoof deformities. This research was conducted on 12 female Brown Swiss dairy cows mid to late lactation period that had healthy hooves showing symptoms lameness due to hoof deformities. Daily feed consumption and milk yield findings were recorded on days the 1,7 (before HT), 13 (on the day of HT), 19,25, and 31 (after HT) of the study. Total oxidant capacity (TOC) and total antioxidant capacity (TAC) tests for determination of oxidative stress index, for the evaluation of antioxidant potential; glutathione peroxidase (GSH-Px), glutathione (GSH), superoxide dismutase (SOD) enzyme, Vitamin $E, A$, and $C$ levels were measured in blood samples taken on the experiment days. According to the findings of this study, after HT increased feed consumption and milk yield in cows ( $\mathrm{P}<$ 0.05). After HT, TOC decreased ( $P<0.05)$, TAC ( $P<0.05)$, GSH-Px $(P<0.05, P<0.001)$, GSH $(P<0.05, P$ $<0.001)$, SOD $(P<0.05, P<0.001)$, Vitamin $E(P<0.05, P<0.001)$ and Vitamin $C(P<0.05)$ levels increased significantly, Vitamin $A(P>0.05)$ levels did not change significantly. Results of this study showed that HT, the oxidant system was suppressed and the antioxidant system was supported in dairy cows with hoof deformities dad healthy hooves.

\section{Introduction}

Hoof deformities and lameness in dairy cows are an increasingly problem in modern dairy farms [1, 2]. Various factors such as sheltering environment, high productivity, high herd density, and individual sensitivity make cows prone to claw disorders [3-7]. Lameness causes significant economic losses in dairy cattle farms and the most important reason of this economic loss is the decrease in milk production [8-13]. After the appearance of lameness, the decrease in milk yield, the cow does not want to go to the manger due to pain, and when it does, barely standing for feed consumption, and therefore feed consumption is reduced. In conclusion, milk yield decreases due to the decrease in feed consumption [14-18]. Additionally to economical losses foot and hoof deformities also adversely influence the cow's welfare [19-21]. Therefore, there is a raising awareness of the importance of HT in cattle in terms of animal health and welfare.

Hoof trimming is done to prevent lesions on the claws and to improve gait by correcting and maintaining foot symmetry and shape, which ensures the correct distribution of weight. Lameness caused by hoof deformities can be treated with correct HT. The correct claw shape helps restore weight-bearing balance and supports recovery from hoof deformities [21-25]. However, the discomfort caused by only deformed hoof structures in the animal and the effect of the correct hoof shape on animal welfare has not been reported. In this study, it was objectived to compare the changes in feed consumption, milk yield, oxidant and antioxidant parameters before and after HT. In addition to previous studies, also with the findings of this study effects of HT on the economy and animal welfare will be revealed.

\section{Materials And Methods}


This research was conducted on 12 female Brown Swiss dairy cows aged 3 - 6 years with a mean bodyweight of $550 \pm 600 \mathrm{~kg}$ that was in the mid to late lactation period that showing symptoms lameness due to only hoof deformities (without lesion in the living tissue of the foot) at the Agri Ibrahim Cecen University Eleskirt Celal Oruc Academy of Livestock Production, Education, Research and Application Farm, Agri, TR. Data were collected for each cow from the farm registration system: age, the first calving age of cows, two birth intervals, the mean number of calving, days in lactation, number of lactation, lactation stage, daily milk yield, stay or removal age in the herd.

\section{Feeding and determination of daily feed consumption}

Cows were fed the same ration during the research. Concentrate (8 $\mathrm{kg}$ milk feed) [Cattle Dairy Feed 18\%, Birlik Feed Erzurum, Turkey] and roughage ( $20 \mathrm{~kg}$ corn silage, $4 \mathrm{~kg}$ clover dry grass, and $3 \mathrm{~kg}$ meadow dry grass) were given immediately after morning and evening milking divided into two in a day fed ad libitum. Daily energy needs were computed from the mean weight and daily milk yield to the National Research Council (NRC) requirements [26]. To determine the daily feed consumption of each cow during the study, the animals in the study group were kept in separate compartments on the farm. They were subjected to individual feeding. Daily total feed consumption, morning and evening before feeding was determined by weighing the increased feed in front of the animals (Jadever JWQ-30 Digital precision scale). Daily feed consumption findings on days the 1,7 (before HT), 13 (on the day of HT), 19, 25, and 31 (after $\mathrm{HT}$ ) of the study were recorded. The mean feed composition is given in Table 1. Clean drinking water was always kept in front of the animals.

\section{Claw trimming}

Twelve cows that dad healthy hooves showing symptoms lameness due to hoof deformities were selected for the study. The health status of the cows was determined by rectal temperature, pulse, and respiration rate 12 hours before HT. Cows showing the values of these 3 parameters outside the physiological range were excluded from the study. On days the $13^{\text {th }}$ of the study, it was taken to the travail that provided the standing fixation of the animal for HT. HT was started from the medial hoof in the hind legs and lateral hoof in the anterior legs. Following the method, the horn hoof was trimmed and corrected by the investigator (SY) and this procedure was completed in approximately $15 \mathrm{~min}$. Claws of the cows were trimmed on different days and checked for hoof disease. The hooves of cows were trimmed following a 1-year interval since the previous trim.

\section{Daily milk yield}

Cows that were in the mid to late lactation stage were chosen for the research. The average days in lactation for the cows were 230.4 (inter 124-289 days) and the average number of calvings was 2.06 times (inter 1-4 times) before HT. The milk yield of 12 cows was recorded twice a day (at 6:00 a.m and $6: 00$ p.m) on days $1,7,13,19,25,31^{\text {st }}$ of the study using an automatic milking system (milkline® milking). 


\section{Biochemical analysis}

On days the $1,7,13,19,25$, and $31^{\text {st }}$ of the study, the blood samples taken into glass tubes with and without anticoagulant were brought to the laboratory as soon as possible and centrifuged at $3000 \mathrm{rpm}$ for 10 minutes at room temperature and stored at $-80 \mathrm{OC}$ until the test. Total oxidant capacity (TOC) [Bovine (TOC) ELISA kit] and total antioxidant capacity (TAC) [Bovine (TAC) ELISA kit] tests for determination of oxidative stress index in serum samples, from antioxidant enzymes for the evaluation of antioxidant potential; Glutathione Peroxidase (GSH-Px) [Glutathione Peroxidase Assay kit], Glutathione (GSH) [Glutathione Assay kit], Superoxide Dismutase (SOD) [Süperoxide Dismutase Assay kit] enzyme levels were measured by ELISA using a commercial kit. Plasma vitamin E and A levels, which are antioxidant vitamins, were determined by using commercial test kits accordance to the technique on the HPLC device (Shimadzu UV-1700, Japon) at Agri Ibrahim Cecen University Central Laboratory. Plasma vitamin $\mathrm{C}$ levels were determined colorimetrically by the appropriate technique using the phosphotungunstic acid method at Kafkas University Central Laboratory [27].

\section{Statistical Analysis}

The one-way analysis of variance (ANOVA) and post hoc Duncan tests were applied to the data to examine the differences among times using the SPSS statistical software package. The findings are showed as average \pm SE. A value of $P<0.05$ was accepted significantly.

\section{Results}

\section{Daily feed consumption (kg)}

In the findings of daily feed consumption on days $1,7,13,19,25$ and $31^{\text {st }}$, in the comparisons between with the day $1^{\text {st }}$, days $7,13,19,25$, and $31^{\text {st }}$, no statistically significant difference was found between with the day $1^{\text {st }}$, days 7 and $13^{\text {th }}(P>0.05)$, a statistically significant result was found between with the day $1^{\text {st }}$, days 19,25 , and $31^{\text {st }}(P<0.05)$ and feed consumption increased on days $19,25,31^{\text {st }}$ according to the day $1^{\text {st }}$. In comparison between the with the days $7^{\text {th }}$, days $13,19,25$, and $31^{\text {st }}$, no statistically significant difference was found between days 7 and $13^{\text {th }}(P>0.05)$, a statistically significant result was found in the between with the days $7^{\text {th }}$, days 19,25 , and $31^{\text {st }}(P<0.05)$ and feed consumption increased on days $19,25,31^{\text {st }}$ according to days 7 . In comparison between with the days $13^{\text {th }}$, days 19,25 , and $31^{\text {st }}$, statistically significant results were found $(P<0.05)$ and feed consumption increased on days $19,25,31^{\text {st }}$ according to days $13^{\text {th }}$. In the comparisons between with the days $19^{\text {th }}$, days 25 and $31^{\text {st }}$, no statistically significant difference was found $(P>0.05)$. No statistically significant difference was found in the comparison between the days 25 and $31^{\text {st }}(P>0.05)$, (Graph 1$)$.

\section{Daily milk yield (L)}


In the findings of daily milk yield on days $1,7,13,19,25$, and $31^{\text {st }}$, in the comparisons between with the day $1^{\text {st }}$, days $7,13,19,25$, and $31^{\text {st }}$, there was no statistically significant difference between with the day $1^{\text {st }}$, days 7,13 , and $19^{\text {th }}(P>0.05)$, a statistically significant difference was found between with the day $1^{\text {st }}$, days 25 and $31^{\text {st }}(P<0.05)$, milk yield increased on the days 25 and $31^{\text {st }}$ according to the day $1^{\text {st }}$. In comparisons between with days $7^{\text {th }}$, days $13,19,25$ and $31^{\text {st }}$, there was no statistically significant difference between the with days $7^{\text {th }}$, days 13 and $19^{\text {th }}(P>0.05)$, the measurement results between with the days $7^{\text {th }}$, days 25 and $31^{\text {st }}$ were statistically significant $(P<0.05)$, milk yield increased on the $25^{\text {th }}$ and $31^{\text {st }}$ days according to the $7^{\text {th }}$ days. In the comparison between with the days $13^{\text {th }}$, days 19,25 , and $31^{\text {st }}$, there was no statistically significant difference between days 13 and $19^{\text {th }}(P>0.05)$, a statistically significant difference was found between with the days $13^{\text {th }}$, days 25 and $31^{\text {st }}(P<0.05)$, and the milk yield increased on the days 25 and $31^{\text {st }}$ according to the days $13^{\text {th }}$. Found statistically significant difference in the comparison between with the days $19^{\text {th }}$, days 25 and $31^{\text {st }}(P<0.05)$, and the milk yield increased on the days 25 and $31^{\text {st }}$ according to the days $19^{\text {th }}$. There was no statistically significant difference in comparison between the days 25 and $31^{\text {st }}(P>0.05)$, (Graph 1$)$.

\section{Oxidant and Antioxidant parameters}

In total oxidant capacity (TOC) measurement results on days $1,7,13,19,25$, and $31^{\text {st }}$, in the comparisons between with the day $1^{\text {st }}$, days $7,13,19,25$, and $31^{\text {st }}$, no statistically significant difference was found between with the day $1^{\text {st }}$, days 7 and $13^{\text {th }}(P>0.05)$, a statistically significant difference was found in the comparisons between with the day $1^{\text {st }}$, days 19,25 , and $31^{\text {st }}(P<0.05)$, and the TOC decreased on days 19,25 , and $31^{\text {st }}$ according to the day $1^{\text {st }}$. In comparisons between with days $7^{\text {th }}$, days $13,19,25,31^{\text {st }}$, there was no statistically significant difference between days 7 and $13(P>0.05)$, a statistically significant difference was found between with the days $7^{\text {th }}$, days 19,25 , and $31^{\text {st }}(P<0.05)$, and TOC decreased on days 19,25 , and $31^{\text {st }}$ according to days $7^{\text {th }}$. In the comparison between with the days $13^{\text {th }}$, days 19,25 , and $31^{\text {st }}$, a statistically significant difference was found between the days $13^{\text {th }}$, days 19,25 , $31^{\text {st }}(P<0.05)$, and TOC decreased on days 19,25 , and $31^{\text {st }}$ according to the days $13^{\text {th }}$. In the comparisons between with the days $19^{\text {th }}$, days 25 and $31^{\text {st }}$, no statistically significant difference was found between the days $19^{\text {th }}$, days 25 and $31^{\text {st }}(P>0.05)$. There was no statistically significant difference in comparison between days the 25 and $31^{\text {st }}(P>0.05)$. TOC decreased after HT.

In total antioxidant capacity (TAC) measurement results on days $1,7,13,19,25$ and $31^{\text {st }}$, in the comparisons between with the day $1^{\text {st }}$, days $7,13,19,25$, and $31^{\text {st }}$, no statistically significant difference was found between days the 1 and $7^{\text {th }}(P>0.05)$, a statistically significant difference was found between the days 1 and $13^{\text {th }}(P<0.05)$, and TAC decreased on days $13^{\text {th }}$, no statistically significant difference was found between with day the $1^{\text {st }}$, days $19,25,31^{\text {st }}(P>0.05)$. In the comparisons between with the days $7^{\text {th }}$, days $13,19,25$, and $31^{\text {st }}$, statistically significant difference was found between the days 7 and $13^{\text {th }}(P$ $<0.05$ ), and TAC decreased on the days $13^{\text {th }}$, no statistically significant difference was found between 
with the days $7^{\text {th }}$, days $19,25,31^{\text {st }}(P>0.05)$. In the comparisons between with the days $13^{\text {th }}$, days 19,25 , and $31^{\text {st }}$, statistically significant difference was found between with the days $13^{\text {th }}$, days 19,25 , and $31^{\text {st }}$ $(P<0.05)$, and TAC increased on days $19,25,31^{\text {th }}$. No statistically significant difference was found in the comparisons between with the days $19^{\text {th }}$, days 25 and $31^{\text {st }}(P>0.05)$. No statistically significant difference was found between the days 25 and $31^{\text {st }}$ comparisons $(P>0.05)$. TAC increased after HT.

In glutathione peroxidase (GSH-Px) measurement results on days $1,7,13,19,25$, and $31^{\text {st }}$, in the comparisons between with the day $1^{\text {st }}$, days $7,13,19,25$, and $31^{\text {st }}$, there was no statistically significant difference between with the day $1^{\text {st }}$, days 7 , and $13^{\text {th }}(P>0.05)$, a statistically significant difference was found between the with day $1^{\text {st }}$, days $19(P<0.05), 25(P<0.05)$, and $31^{\text {st }}(P<0.001)$, GSH-Px activity increased on days 19,25 , and $31^{\text {st }}$. In comparisons between with the days $7^{\text {th }}$, days $13,19,25$, and $31^{\text {st }}$, there was no statistically significant difference between days 7 and $13^{\text {th }}(P>0.05)$, a statistically significant difference was found between with the days $7^{\text {th }}$, days $19(P<0.05), 25(P<0.05)$, and $31^{\text {st }}(P<$ 0.001 ), and GSH-Px activity increased on days 19,25 , and 31 . In the comparisons between with the days $13^{\text {th }}$, days 19,25 , and $31^{\text {st }}$, a statistically significant difference was found between with the days $13^{\text {th }}$, days $19(P<0.05), 25(P<0.05)$, and $31^{\text {st }}(P<0.001)$, GSH-Px activity increased on days 19,25 , and $31^{\text {st }}$. In the comparison between with the days $19^{\text {th }}$, days 25 , and $31^{\text {st }}$, there was no statistically significant difference between with the days $19^{\text {th }}$, days 25 , and $31^{\text {st }}(P>0.05)$. There was no statistically significant difference in comparison between days the 25 and $31^{\text {st }}(P>0.05)$. GSH-Px activity increased after HT.

In glutathione (GSH) measurement results on days $1,7,13,19,25$, and $31^{\text {st }}$, in the comparison between with the day $1^{\text {st }}$, days $7,13,19,25$, and $31^{\text {st }}$, a statistically significant difference was found between with the day $1^{\text {st }}$, days 7 and $13^{\text {th }}(P<0.05)$, GSH levels decreased on days 7 and $13^{\text {th }}$, there was no statistically significant difference between days 1 and $19^{\text {th }}(P>0.05)$, a statistically significant difference was found between with the day $1^{\text {st }}$, days 25 and $31^{\text {st }}(P<0.001)$, GSH levels increased on days 25 and $31^{\text {st }}$. In the comparison between with the days $7^{\text {th }}$, days $13,19,25$ and $31^{\text {st }}$, there was no statistically significant difference between days 7 and $13^{\text {th }}(P>0.05)$, a statistically significant difference was found between with days $7^{\text {th }}$, days $19(P<0.05), 25(P<0.001)$ and $31^{\text {st }}(P<0.001)$, and GSH level increased on days 19 , 25 and $31^{\text {st }}$. In the comparisons between with the days $13^{\text {th }}$, days 19,25 , and $31^{\text {st }}$, there was a statistically significant difference between with $13^{\text {th }}$, days $19(P<0.05), 25(P<0.001)$ and $31^{\text {st }}(P<$ $0.001)$, and GSH level increased on days 19,25 , and $31^{\text {st }}$. A statistically significant difference was found in the comparisons between days $19^{\text {th }}$, days 25 and $31^{\text {st }}(P<0.001)$, and GSH level increased on days 25 and $31^{\text {st }}$. A statistically significant difference was found in the comparison between the days 25 and $31^{\text {st }}$ $(P<0.05)$, and GSH level increased on days $31^{\text {st }}$ according to days $25^{\text {th }}$. GSH level increased after HT

In superoxide dismutase (SOD) measurement results on days $1,7,13,19,25$, and $31^{\text {st }}$, in the comparison between with the day $1^{\text {st }}$, days $7,13,19,25$, and $31^{\text {st }}$, there was no statistically significant difference between with the day $1^{\text {st }}$, days 7 and $13^{\text {th }}(P>0.05)$, there were statistically significant between with the 
day $1^{\text {st }}$, days $19(P<0.05), 25(P<0.001)$ and $31^{\text {st }}(P<0.001)$, and SOD activity increased on days 19,25 , and $31^{\text {st }}$. In comparisons between with days $7^{\text {th }}$, days $13,19,25$, and $31^{\text {st }}$, there was no statistically significant difference between the measurement results between days 7 and $13^{\text {th }}(P>0.05)$, a statistically significant difference was found between with the days $7^{\text {th }}$, days $19(P<0.05), 25(P<0.001)$ and $31^{\text {st }}(P$ $<0.001$ ), and SOD activity increased on days 19,25 , and $31^{\text {st }}$. A statistically significant difference was found in the comparison between with the days $13^{\text {th }}$, days $19(P<0.05), 25(P<0.001)$, and $31^{\text {st }}(P<$ $0.001)$, and the SOD activity increased on days 19,25 , and $31^{\text {st }}$. A statistically significant difference was found between with the days $19^{\text {th }}$, days 25 and $31^{\text {st }}(P<0.05)$, and SOD activity increased on days 25 and $31^{\text {st }}$. There was no statistically significant difference in comparison between the days 25 and $31^{\text {st }}(P$ $>0.05)$. SOD activity increased after HT.

In vitamin C measurement results on days $1,7,13,19,25$, and $31^{\text {st }}$, in the comparison between with the day $1^{\text {st }}$, days $7,13,19,25$, and $31^{\text {st }}$, there was no statistically significant difference between with the day $1^{\text {st }}$, days 7 and $13^{\text {th }}(P>0.05)$, there was a statistically significant difference between with the day $1^{\text {st }}$, days $19^{\text {th }}, 25^{\text {th }}$, and $31^{\text {st }}(P<0.05)$, vitamin $C$ level increased on days $19^{\text {th }}, 25^{\text {th }}$, and $31^{\text {st }}$ according to the day $1^{\text {st }}$. In the comparison between with the days $7^{\text {th }}$, days $13,19,25$, and $31^{\text {st }}$, while there was no statistically significant difference between days $7^{\text {th }}$ and $13^{\text {th }}(P>0.05)$, there was a statistically significant difference between with the days $7^{\text {th }}$, days $19^{\text {th }}, 25^{\text {th }}$, and $31^{\text {st }}(P<0.05)$. In the comparison between with the day $13^{\text {th }}$, days 19,25 , and $31^{\text {st }}$, a statistically significant difference was found between the days $13^{\text {th }}$, days $19^{\text {th }}, 25^{\text {th }}$, and $31^{\text {st }}(P<0.05)$. In the comparison between with the day $19^{\text {th }}$, days 25 and $31^{\text {st }}$, there was no statistically significant difference in comparisons between with the days $19^{\text {th }}, 25^{\text {th }}$, and $31^{\text {st }}$ days $(P>$ 0.05). There was no statistically significant difference in comparison between the days 25 and $31^{\text {st }}(P>$ 0.05). Vitamin C level increased after HT.

In vitamin E measurement results, in the comparison between with the day $1^{\text {st }}$, days $7,13,19,25$, and $31^{\text {st }}$, no statistically significant difference was found between with the day $1^{\text {st }}$, days $7,13,19^{\text {th }}(P>0.05)$, there was a statistically significant difference between days $25^{\text {th }}(P<0.05)$, and $31^{\text {st }}(P<0.001)$. Vitamin $\mathrm{E}$ level increased on the $25^{\text {th }}$ and $31^{\text {st }}$ days compared to the day $1^{\text {st }}$. In the comparison between with the day $7^{\text {th }}$, days $13,19,25$, and $31^{\text {st }}$, there was no statistically significant difference between with the days $7^{\text {th }}$, days $13^{\text {th }}$ and $19^{\text {th }}(P>0.05)$, while there was a statistically significant difference between days $25^{\text {th }}$ $(P<0.05)$, and $31^{\text {st }}(P<0.001)$. In the comparison between with the days $13^{\text {th }}$, days 19,25 , and $31^{\text {st }}$, there was no significant difference in the comparisons between the $13^{\text {th }}$ and $19^{\text {th }}$ days $(P>0.05)$, there was a statistically significant difference in the comparisons between days $25^{\text {th }}(P<0.05)$, and $31^{\text {st }}(P<0.001)$. There was a statistically significant difference in the comparisons between with the days $19^{\text {th }}, 25^{\text {th }}$, and $31^{\text {st }}$ days $(P<0.05)$. There was a statistically significant difference in the comparisons between the days $25^{\text {th }}$ and $31^{\text {st }}(P<0.05)$. Vitamin $E$ level increased after $\mathrm{HT}$. 
In vitamin A measurement results, there was no statistically significant difference in comparisons between all time $(P>0.05)$. Vitamin A level did not change after HT.

Measurement results of oxidant and antioxidant parameters on days $1,7,13,19,25,31^{\text {st }}$ of the study are given in Table 2.

\section{Discussion}

Many factors genetics, season, shelter type, herd size, exercise, lying surface, age, pregnancy and lactation, and feeding conditions are effective on foot health. One or more of these factors come together to determine the herd's foot health [28-31]. Regular hoof trimming is the only way to minimize the effects of these factors [32]. Functional HT, disrupts the vicious circle of excessive mechanical load on the claw, ensuring that the weight is evenly distributed on both claws. Healthy claw tissue production is stimulated as the pressure on keratogenic cells will increase with routine HT in thin bottomed animals [33-36].

In research by Aoki et al. [37], it has been quantitatively showing that walking characteristics are improved after HT. Phillips et al. [38] have shown that HT body weight is distributed evenly on the foot and therefore on the claws and suggested a corresponding influence on posture. Nishimori et al. [39] reported a possibility that a change in weight-bearing and posture may affect dry matter intake. They showed that by measuring different blood measurement parameters, cows started eating more roughage after HT. In the present study, each cow included in the study were subjected to individual feeding separate compartment to determine the effect on feed consumption of HT and daily feed consumption was measured on days 1,7,13,19,25, and 31st of the study. Cows' claws were trimmed on days the 13th of the study. Although the day of the HT was not statistically significant, the feed consumption of cows decreased temporarily compared to the $1 \mathrm{st}$ and 7 th days of the study. The slightly reduced in feed consumption on the day of trimming can be attributed to the stress occurring in the animal due to HT, interruption of the daily routine and the fact that it does not yet take the normal shape of the claw and does not press the ground completely and does not adapt to the new claw of the animal, on the days following HT in cows had a decrease in activity for all these reasons feed consumption decreased. In the measurements made on the 19th, 25th, and 31st days after HT feed consumption was found to increase statistically significantly. Feed consumption started to increase on days the 6th (on days the 19th of study) after HT may be attributed to the normal shape of the claw and the animal can comfortably step on the ground. Lastly, the increase in feed consumption after HT can be attributed to getting healthy claws of the animals. It was also revealed by the findings of this study that HT increased feed consumption in cows.

Claw health has a pronounced effect on milk production $[2,6,8,9,11,40]$. Cows with painful hoof disorders eat less food, are less willing to move, and as a result, they can yield less milk than cows without claw disorders. Likely, the decrease in milk production associated with foot and claw lesions is due to raised energy requirement due to pain, which may also be current without a decrease in feed consumption or a noticeable lameness $[2,4,11,27]$. Several studies showed the expected decrease in 
milk production in cows with claw and limb disorders. In a study by Sogstad et al. [41] cows are reported to give more milk after HT than before HT. In another study by Kibar and Caglayan [42] they determined that HT of a one-time hoof increased milk production in dairy cattle with hoof disorders in commercial dairy farms. But in some studies, higher milk yield was not detected after $\mathrm{HT}$. In a study investigated the effects on milk yield of one-time HT by Nishimori et al. [38], demonstrated that milk yield did not change after $\mathrm{HT}$. Taguchi et al. [43] have reported a similar experiment, but no differences in milk production and composition were showed in their research. In another study by Tanaka et al. [33], observed that HT slows down the rate at which milk production reductions in cows in the late lactation period. As many researchers have reported $[4,13,23,30]$, milk yield in the lactation stage is effected by herd factors such as management and nutrition and individual factors as genetics, parity, and disease. Differences in the literature about the influence of lameness and hoof disorders on milk production are comparatively the conclusion of these complex effects. In the current study, daily milk yield findings were recorded on days $1,7,13,19,25$, and 31 st of the research to determine the effect of HT on milk yield in healthy cows. No diversity was showed in milk production in the measurements made on days 1,7 (before HT), 13 (on the day of $\mathrm{HT}$ ). On the day of $\mathrm{HT}$, the daily milk yield showed not change according to days 1 and 7 th, and also the time needed for the complete HT procedure with a mean of 15 minutes was very short. On the 6th day after the HT (days 19th of the study), milk yield was increased, though not statistically significant. On the 25 and 31 st days of the study (after HT), a statistically significant difference was observed in the increase of milk yield. On days 10th after HT on the daily milk yield had recovered to its original value (on days 25th of study) and final measurements were made on the 31st day of the study. Accordingly, milk yield after HT was higher than before HT. Subsequently, milk yield was increased after $H T$. Results of the current study concurred with the findings of some researchers [33,41,42] increased in the milk yield following HT. Increased milk production after HT can be increased feed consumption as a conclusion of having healthier hooves and walking more comfortably and standing because of smooth hoof figure then HT. In the current study, a 0.9 positive relation between feed consumption and daily milk yield was also shown.

Claw disorders can be responsible for the deterioration of animal welfare by causing pain and stress in cattle [44-47]. Oxidant and antioxidant parameters are often used to assess pain and stress in animals [36]. However, in the literature searches, no publication investigating the effect on the oxidant and antioxidant system of HT to evaluate the pain and stress caused by claw disorder in cattle. For this reason, this study also aimed to determine the effect on oxidant and antioxidant systems of HT in cows.

Under normal conditions, oxidants and antioxidants are in balance in the organism. However, in situations such as inflammation, infection, pain, and stress, this balance is disrupted in favor of oxidants, and free radicals occur, which can cause damage to cells or tissues [48].

It is recommended to measure TOC and TAC to determine the oxidant and antioxidant status in the organism and their balance. In this study, a significant decrease in TOC values was observed in the measurement results after the HT. In TAC measurements, the day of HT decreased significantly and showed a significant increase in measurement days after HT. GSH-Px is the most effective of antioxidant 
enzymes. It is responsible for the destruction of intracellular hydroperoxides. By converting $\mathrm{H}_{2} \mathrm{O}_{2}$ to water, prevents the formation of methemoglobin and protects the membrane lipids against peroxide anion, and protects the integrity of the cell membrane. GSH-Px values were significantly lower before and on the days of HT, there was a significant increase in the measurements made after HT. GSH is an important intracellular nonenzymatic antioxidant. Its oxidized form is involved in the inhibition of free radicals, stabilization of reduced sulfhydryl groups, and regeneration of tocopherol and ascorbate. It also acts as the cofactor of GSH-Px. GSH values were significantly lower before HT and on the days of HT, there was a significant increase in the measurements made after HT. SOD is the first enzyme to act in the antioxidative system, which is found in the mitochondria matrix of hepatocytes, erythrocytes, and brain cells. It has a stable structure. It catalyzes the reaction that converts $\mathrm{O}_{2}$ - to $\mathrm{H}_{2} \mathrm{O}_{2}$. SOD values were significantly lower before $\mathrm{HT}$ and on the days of $\mathrm{HT}$, there was a significant increase in the measurements made after HT. The low levels of GSH-Px, GSH, SOD before HT are thought to be due to their use in order to neutralize the radicals that occur due to oxidative stress developing during lameness.

The synergism between Vitamin $\mathrm{C}$ and $\mathrm{E}$ in preventing lipid peroxidation is well known. While Vitamin $\mathrm{C}$ increases the antioxidant effect of Vitamin $\mathrm{E}$, it also reduces its consumption. Under normal conditions, Vitamin $C$ is synthesized by the liver of adult cattle and this synthesis is sufficient for physiological needs. However, ruminants are susceptible to deficiencies due to the destruction of Vitamin $\mathrm{C}$ by the rumen microflora. Vitamin $\mathrm{C}$ deficiency also reduces the body's defense power against infections. In the present study, it is noteworthy that after $\mathrm{HT}$, Vitamin $\mathrm{E}$ and $\mathrm{C}$ levels were significantly increased in cattle compared to before. It is thought that the reason for this situation is the decrease in feed consumption due to lameness and the increasing use due to developing oxidative stress. On the other hand, in Vitamin A levels, no significant change was observed in concentrations at study through. This may be related to the use of vitamins such as $\mathrm{E}$ and $\mathrm{C}$ primarily during oxidative stress.

This study showed that after $\mathrm{HT}$, the oxidant system was suppressed and the antioxidant system was supported in dairy cows. In this study, it has been shown with the findings of the oxidant and antioxidant defense system that HT increases animal welfare in cattle.

\section{Conclusions}

In this study, an increase in feed consumption and milk yield was observed after HT. At the same time, in this study where the effects of HT on the oxidant and antioxidant system were investigated, it was observed that the oxidant system was suppressed and the antioxidant system was supported after the HT. In light of all this information, the hypothesis that HT the necessity of regular claw trimming to ensure healthy claws and prevent lameness is clear, and it is, therefore, an integral part of improving the welfare of cattle was confirmed.

\section{Declarations}

\section{Acknowledgments}


Thank you to lecturer Prof. Dr. Onur ATAKişi at Kafkas University, Faculty of Arts and Sciences, Department of Chemistry, Department of Biochemistry for his help during the analysis of biochemical parameters.

Ethical approval The study was approved by the animal local Ethics Committee (ÇÜ, HAYDEK Date: 06.07.2017. Number: 2017-058), Cukurova University.

\section{References}

1. Bicalho RC, Oikonomou G (2013) Control and prevention of lameness associated with claw lesions in dairy cows. Livestock Sci 156(1-3):96-105

2. Flower FC, Sanderson DJ, Weary DN (2006) Effects of milking on dairy cow gait. J Dairy Sci 89(6):2084-2089

3. Somers JGCJ, Frankena K, Noordhuizen-Stassen EN, Metz JHM (2003) Prevalence of claw disorders in Dutch dairy cows exposed to several floor systems. J Dairy Sci 86(6):2082-2093

4. Bielfeldt JC, Badertscher R, Tölle KH, Krieter J (2005) Risk factors influencing lameness and claw disorders in dairy cows. Livestock Sci 95(3):265-271

5. Manske T, Hultgren J, Bergsten C (2002) The effect of claw trimming on the hoof health of Swedish dairy cattle. Prev Vet Med 54(2):113-129

6. Demirkan I, Murray R, Carter S (2000) Skin diseases of the bovine digit associated with lameness. Vet Bull 70:149-171

7. Faye B, Lescourret F (1989) Environmental factors associated with lameness in dairy cattle. Prev Vet Med 7(4):267-287

8. Entig H, Kooji D, Dijkhuizen AA, Huirne RBM, Nordhuizen-Stassen EN (1997) Economic losses due to clinical lameness in dairy cattle. Livestock Sci 49(3):259-267

9. Charfeddine N, Perez-Cabal MA (2017) Effect of claw disorders on milk production, fertility, and longevity, and their economic impact in Spanish Holstein cows. J Dairy Sci 100(1):653-665

10. Onyiro OM, Offer J, Brotherstone S (2008) Risk factors and milk yield losses associated with lameness in Holstein-Friesian dairy cattle. Animal 2(8):1230-1237

11. Reader JD, Green MJ, Kaler J, Mason SA, Green LE (2011) Effect of mobility score on milk yield and activity in dairy cattle. J Dairy Sci 94(10):5045-5052

12. Sogstad ÅM, Østerås O, Fjeldaas T, Refsdal AO (2007) Bovine claw and limb disorders at claw trimming related to milk yield. J Dairy Sci 90(2):749-759

13. Demir P, Yayla S, Aksoy O, Ozaydin I (2013) Financial losses from foot diseases in cattle farms in Kars Province. Turkish J Vet Anim Sci 37(1):20-25

14. González LA, Tolkamp BJ, Coffey MP, Ferret A, Kyriazakis I (2008) Changes in feeding behavior as possible indicators for the automatic monitoring of health disorders in dairy cows. J Dairy Sci 91(3):1017-1028 
15. Arican M, Hatipoglu F, Erol H, Kanat O, Yavuz O, Parlak K, Koc O (2018) Comparison of thermographic imaging and other diagnostic techniques in the diagnosis of cattle with laminitis. Acta Sci Vet 46:17

16. Hassall SA, Ward W, Murray R (1993) Effects of lameness on the behavior of cows during the summer. Vet Rec 132(23):578-580

17. Warnick LD, Janssen D, Guard CL, Gröhn YT (2001) The effect of lameness on milk production in dairy cows. J Dairy Sci 84(9):1988-1997

18. Green LE, Hedges VJ, Schukken YH, Blowey RW, Packington AJ (2002) The impact of clinical lameness on the milk yield of dairy cows. J Dairy Sci 85(9):2250-2256

19. Alvergnas M, Strabel T, Rzewuska K, Sell-Kubiak E (2019) Claw disorders in dairy cattle: Effects on production, welfare and farm economics with possible prevention methods. Livestock Sci 222(4):54-64

20. Stoddard GC, Cramer G (2017) A review of the relationship between hoof trimming and dairy cattle welfare. Vet Clin North Am Food Anim Pract 33(2):365-375

21. Yakan S, Duzguner V (2019) Effects of meloxicam on stress and oxidative stress in dairy cows undergoing hoof trimming. Fresen Environ Bull 28(4):2697-2702

22. Shearer JK, van Amstel SR (2001) Functional and corrective claw trimming. Vet Clin North Am Food Anim Pract 17(1):53-72

23. Van der Tool PPJ, Van der Beek SS, Metz JHM, Noordhuizen Stassen EN, Back W, Braam CR, Weijs WA (2004) The effect of preventive trimming on weight bearing and force balance on the claws of dairy cattle. J Dairy Sci 87(6):1732-1738

24. Pesenhofer G, Palme R, Pesenhofer RM, Kofler J (2006) Comparison of two methods of fixation during functional claw trimming - walk-in crush versus tilt table - in dairy cows using fecal cortisol metabolite concentrations and daily milk yield as parameters. Wien Tierärztl Mschr 93:288-294

25. Neveux S, Weary DM, Rushen J, von Keyserlingk MAG, de Passillé AM (2006) Hoof discomfort changes how dairy cattle distribute their body weight. J Dairy Sci 89(7):2503-2509

26. National Research Council (NRC) (1989) Nutrient Requirements of Dairy Cattle, 6th edn. National Academy Press, Washington, DC

27. Kyaw A (1978) A simple colorimetric method for ascorbic acid determination in blood plasma. Clin Chim Acta 16:151-157

28. Van der Waaij EH, Holzhauer M, Ellen E, Kamphuis C, de Jong G (2005) Genetic parameters for claw disorders in Dutch dairy cattle and correlations with conformation traits. J Dairy Sci 88(10):36723678

29. Frankena K, Somers JG, Schouten WG, van Stek JV, Metz JHM, Stassen EN, Graat EAM (2009) The effect of digital lesions and floor type on locomotion score in Dutch dairy cows. Prev Vet Med $88(2): 150-157$ 
30. Dippel S, Dolezal M, Brenninkmeyer C, Brinkmann J, March S, Knierim U, Winckler C (2009) Risk factors for lameness in freestall-housed dairy cows across two breeds, farming systems, and countries. J Dairy Sci 92(11):5476-5486

31. Cramer G, Lissemore KD, Guard CL, Leslie KE, Kelton DF (2009) Herd-level risk factors for seven different foot lesions in Ontario Holstein cattle housed in tie stalls or free stalls. J Dairy Sci 92(4):1404-1411

32. Van Hertem T, Parmet Y, Steensels M, Maltz E, Antler A, Schlageter-Tello AA, Lokhorst C, Romanini CEB, Viazzi S, Bahr C, Berckmans D, Halachmi I (2014) The effect of routine hoof trimming on locomotion score, ruminating time, activity, and milk yield of dairy cows. J Dairy Sci 97(8):48524863

33. Bryan M, Tacoma H, Hoekstra F (2012) The effect of hindclaw height differential and subsequent trimming on lameness in large dairy cattle herds in Canterbury, New Zealand. New Zealand Vet $J$ 60(6):349-355

34. Van der Tol PPJ, van der Beek SS, Metz JHM, Noordhuizen-Stassen EN, Back W, Braam CR, Weijs WA (2004) The effect of preventive trimming on weight bearing and force balance on the claws of dairy cattle. J Dairy Sci 87(6):1732-1738

35. Kummer M, Gygax D, Lischer C, Auer J (2009) Comparison of the trimming procedure of six different farriers by quantitative evaluation of hoof radiographs. Vet $\mathrm{J}$ 179(3):401-406

36. Erol H, Atalan G, Yonez MK, Ozkocak TB (2019) The Effect of hoof trimming on milk yield in dairy cattle. Int J Sci Technol Res 5(5):51-56

37. Aoki Y, Kamo M, Kawamoto H, Zhang J, Yamada A (2006) Changes in walking parameters of milking cows after hoof trimming. Anim Sci J 77:103-109

38. Phillips CJC, Chiy PC, Bucktrout MJ, Collins SM, Gasson CJ, Jenkins AC, Paranhos Da Costa MJR (2000) Frictional properties of cattle hooves and their conformation after trimming. Vet Rec 146:607-609

39. Nishimori K, Okada K, Ikuta K (2006) The effects of one-time hoof trimming on blood biochemical composition, milk yield, and milk composition in dairy cows. J Vet Med Sci 68:267-270

40. Coulon JB, Lescourret F, Fonty A (1996) Effect of foot lesions on milk production by dairy cows. J Dairy Sci 79(1):44-49

41. Sogstad ÅM, Østerås O, Fjeldaas T, Refsdal AO (2007) Bovine claw and limb disorders at claw trimming related to milk yield. J Dairy Sci 90(2):749-759

42. Kibar M, Caglayan T (2016) Effect of hoof trimming on milk yield in dairy cows with foot disease. Acta Sci Vet 44:1-7

43. Taguchi K, Sagawa S, Otani M, Iketaki T, Soehartono RH, Yamada H (2001) Effects of periodic hoof trimming on milk production in healthy cows. J Jpn Vet Med Assoc 54:269-271

44. Bustamante HA, Rodriguez AR, Herzberg DE, Werner MP, Rodríguez AR, Herzberg DE, Werner MP (2015) Stress and pain response after oligofructose induced-lameness in dairy heifers. J Vet Sci $16(4): 405-411$

Page 13/16 
45. O'Callaghan KA, Cripps PJ, Downham DY, Murray RD (2003) Subjective and objective assessment of pain and discomfort due to lameness in dairy cattle. Animal Welf 2(4):605-610

46. Shearer JK, Stock ML, Van Amstel SR, Coetzee JF (2013) Assessment and management of pain associated with lameness in cattle. Vet Clin North Am Anim Pract 29(1):135-156

47. Stock ML, Millman ST, Barth LA, Van Engen NK, Hsu WH, Wang C, Gehring R, Parsons RL, Coetzee JF (2015) The effects of firocoxib on cautery disbudding pain and stress responses in preweaned dairy calves. J Dairy Sci 98(9):6058-6069

48. Halliwell B, Gutteridge JMC (1989) Lipid peroxidation: A radical chain reaction. In: Free Radicals in Biology and Medicine. 2nd edition, Oxford University Press, New York;188-218

\section{Tables}

Table 1 Composition of concentrated and roughage mixes used in the study. 


\section{Corn silage}

8

Clover dry grass

20

Meadow dry grass

Salt

0.004

Vitamin-mineral premix*

0.003

*Provided per 1 kg of premix: Vitamin A 15000000 IU, Vitamin D3 3000000 IU, Vitamin E 30000 mg, Mn 50000 mg, Zn 50000 mg, Fe 50000 mg, Cu 10000 mg, I 800 mg, Co 150 mg, Se 150 mg.

Table 2 Measurement results of oxidant and antioxidant parameters on days the 1,7 (before HT), 13 (on the day of HT), 19, 25, and 31 ${ }^{\text {st }}$ (after HT)

of the study (mean \pm S.D.)

A statistically significant difference was found between values with different letters in the same column on days 1,7 (before HT), 13 (on the day of HT), 19, 25, and $31^{\text {st }}$ (after HT) of the study $(P<0.05, P<0.001)$.

TOC: total oxidant capacity; TAC: total antioxidant capacity; GSH-Px: glutathione peroxidase; GSH: glutathione, SOD: superoxide dismutase; HT: hoof trimming.

\begin{tabular}{ccccccccc}
\hline $\begin{array}{c}\text { Time } \\
(\text { days })\end{array}$ & $\begin{array}{c}\text { TOC } \\
(\mu \mathrm{mol} / \mathrm{L})\end{array}$ & $\begin{array}{c}\text { TAC } \\
(\mathrm{U} / \mathrm{mL})\end{array}$ & $\begin{array}{c}\text { GSH-Px } \\
(\mathrm{mmol} / \mathrm{L})\end{array}$ & $\begin{array}{c}\text { GSH } \\
(\mathrm{mmol} / \mathrm{L})\end{array}$ & $\begin{array}{c}\text { SOD } \\
(\mathrm{U} / \mathrm{mL})\end{array}$ & $\begin{array}{c}\text { Vitamin } \\
\mathrm{C} \\
(\mathrm{mg} / \mathrm{L})\end{array}$ & $\begin{array}{c}\text { Vitamin } \\
(\mathrm{mg} / \mathrm{L})\end{array}$ & $\begin{array}{c}\text { Vitamin } \\
(\mathrm{mg} / \mathrm{L})\end{array}$ \\
\hline 1 & $64.29 \pm$ & $4.27 \pm$ & $4.51 \pm$ & $15.08 \pm$ & $8.05 \pm$ & $5.84 \pm$ & $5.11 \pm$ & $0.51 \pm$ \\
& $5.71^{\mathrm{a}}$ & $0.22^{\mathrm{a}}$ & $0.43^{\mathrm{a}}$ & $0.45^{\mathrm{a}}$ & $0.25^{\mathrm{a}}$ & $0.94^{\mathrm{a}}$ & $0.28^{\mathrm{a}}$ & $0.05^{\mathrm{a}}$ \\
7 & $60.00 \pm$ & $4.07 \pm$ & $4.46 \pm$ & $12.43 \pm$ & $7.80 \pm$ & $5.69 \pm$ & $5.44 \pm$ & $0.58 \pm$ \\
& $5.34^{\mathrm{a}}$ & $0.26^{\mathrm{a}}$ & $0.33^{\mathrm{a}}$ & $0.62^{\mathrm{ab}}$ & $0.29^{\mathrm{a}}$ & $0.71^{\mathrm{a}}$ & $1.13^{\mathrm{a}}$ & $0.51^{\mathrm{a}}$ \\
13 & $70.00 \pm$ & $3.87 \pm$ & $4.43^{ \pm}$ & $13.50 \pm$ & $7.71 \pm$ & $5.01 \pm$ & $5.28 \pm$ & $0.46 \pm$ \\
& $7.87^{\mathrm{a}}$ & $0.28^{\mathrm{ab}}$ & $0.26^{\mathrm{a}}$ & $0.48^{\mathrm{ab}}$ & $0.20^{\mathrm{a}}$ & $0.21^{\mathrm{a}}$ & $2.11^{\mathrm{a}}$ & $0.45^{\mathrm{a}}$ \\
19 & $45.71 \pm$ & $4.44 \pm$ & $6.00 \pm$ & $16.06 \pm$ & $9.67 \pm$ & $6.99 \pm$ & $5.49 \pm$ & $0.44 \pm$ \\
& $4.81^{\mathrm{ab}}$ & $0.12^{\mathrm{a}}$ & $0.38^{\mathrm{ab}}$ & $0.67^{\mathrm{a}}$ & $0.49^{\mathrm{ab}}$ & $078^{\mathrm{b}}$ & $3.12^{\mathrm{a}}$ & $0.43^{\mathrm{a}}$ \\
25 & $41.43 \pm$ & $4.51 \pm$ & $5.90 \pm$ & $22.97 \pm$ & $10.61 \pm$ & $7.39 \pm$ & $7.11 \pm$ & $0.51 \pm$ \\
& $4.04^{\mathrm{ab}}$ & $0.10^{\mathrm{a}}$ & $0.24^{\mathrm{ab}}$ & $1.11^{\mathrm{abc}}$ & $0.36^{\mathrm{abc}}$ & $0.76^{\mathrm{b}}$ & $0.22^{\mathrm{b}}$ & $0.21^{\mathrm{a}}$ \\
31 & $42.86 \pm$ & $4.43 \pm 0.11^{\mathrm{a}}$ & $6.50 \pm$ & $26.83 \pm$ & $10.64 \pm$ & $7.45 \pm$ & $8.13 \pm$ & $0.43 \pm$ \\
& $7.14^{\mathrm{ab}}$ & & $0.14^{\mathrm{ab}}$ & $1.34^{\mathrm{abcd}}$ & $0.24^{\mathrm{abc}}$ & $0.55^{\mathrm{b}}$ & $2.66^{\mathrm{ab}}$ & $0.11^{\mathrm{a}}$ \\
\hline
\end{tabular}




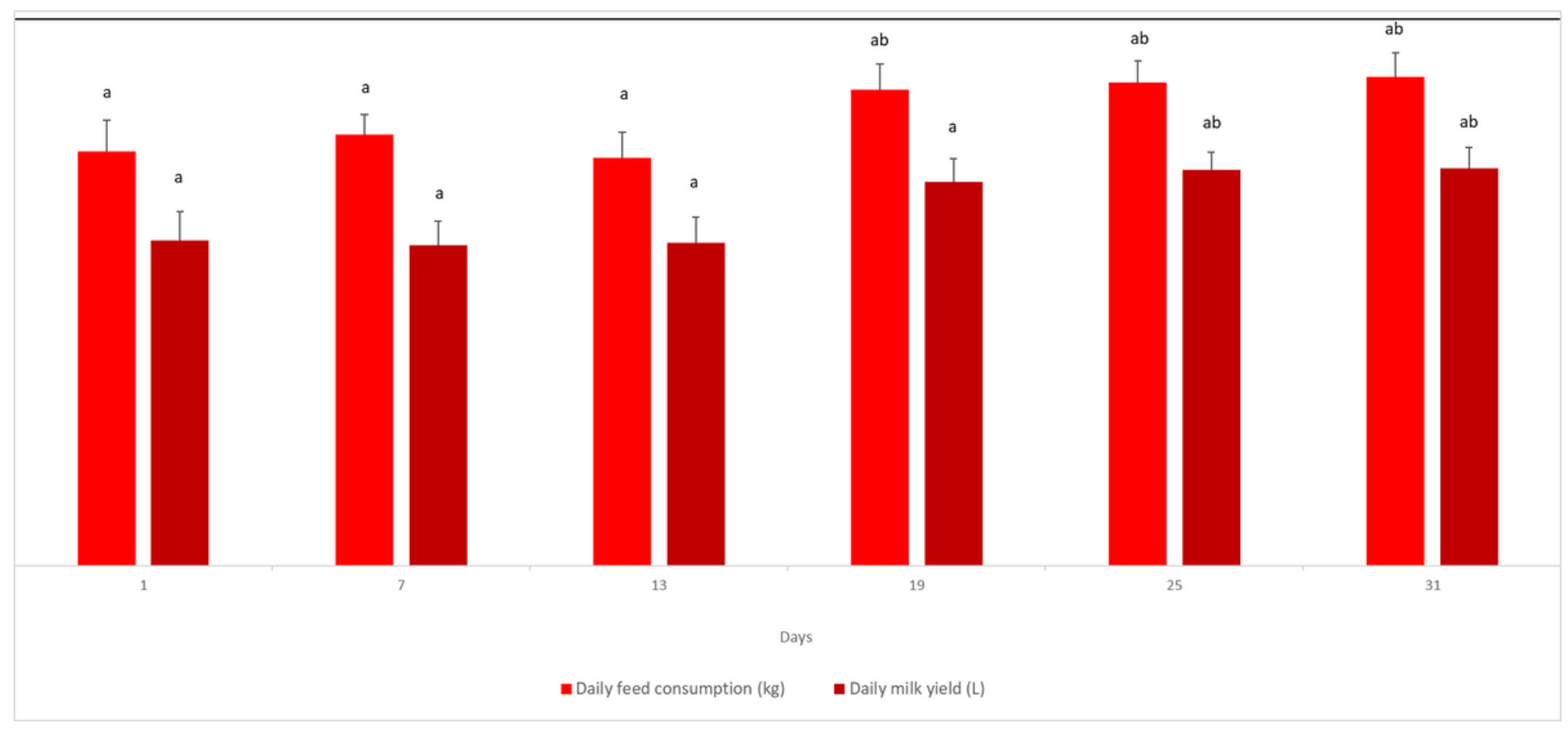

Figure 1

A statistically significant difference was found between columns with different letters in the graph of daily feed consumption and milk yield measurement results on days 1,7 (before HT), 13 (on the day of $\mathrm{HT}), 19,25$, and 31 st (after HT) of the study $(\mathrm{P}<0.05)$; HT: hoof trimming. 